\title{
Effect of Pre- and Post-Weaning High-Fat Dietary Manipulation on Intestinal Microflora and Alkaline Phosphatase Activity in Male Rats
}

\author{
Z. ŠEFČÍKOVÁ ${ }^{1}$, D. BUJŇÁKOVÁ ${ }^{1}$ \\ ${ }^{1}$ Institute of Animal Physiology, Slovak Academy of Sciences, Košice, Slovak Republic
}

Received October 4, 2016

Accepted January 6, 2017

On-line April 12, 2017

\section{Summary}

We investigated the impact of a high-fat (HF) diet during pre- and post-weaning periods on the intestinal microbiota and alkaline phosphatase (AP) activity in male rats. Nutrition from birth was influenced by feeding rat dams with either a standard or HF diet. After weaning male pups nursed by control dams continued on a standard diet (CC) or HF diet ( $\rightarrow \mathrm{HF})$, while offspring nursed by HF dams continued on HF diet (HF) or standard diet $(\mathrm{HF} \rightarrow \mathrm{C})$. The numbers of Bacteroides/Prevotella (BAC) and Lactobacillus/Enterococcus (LAB) in the gut were determined by FISH technique. HF pups displayed enhanced adiposity and increased AP activity (19\%), as well as higher LAB $(P<0.001)$ and lower numbers of $B A C(P<0.001)$ in the jejunum and colon than controls. In $\mathrm{HF} \rightarrow \mathrm{C}$ rats, post-weaning lower fat intake resulted in decreased fat deposition accompanied by reduced AP activity ( $20 \%$ ) compared to HF rats. Composition of the intestinal microbiota in these rats was not influenced. In contrast, in comparison with controls, $\mathrm{C} \rightarrow \mathrm{HF}$ rats displayed higher $L A B(P<0.001)$ and lower BAC $(P<0.001)$ together with increased adiposity and AP activity (14\%). These results indicate that consumption of diet with different fat content could modulate gut microbial/functional conditions depending on the period when the nutritional manipulation occurs.

\section{Key words}

Diet-induced obesity - Intestinal microflora - Alkaline phosphatase activity

\section{Corresponding author}

Z. Šefčíková, Institute of Animal Physiology, Slovak Academy of Sciences, Šoltésovej 4-6, 04001 Košice, Slovak Republic. Fax: +42155 7287842. E-mail: sefcikz@saske.sk

\section{Introduction}

Life-style changes, especially the consumption of high-fat (HF), caloric-dense foods combined with reduced physical activity, have led to an alarming increase in the incidence of obesity around the world. Obesity as a multifactorial disease results from interaction between genetic and environmental factors. The gastrointestinal tract is an important organ responsible for food intake, nutrient digestion and absorption. At present there are still many unanswered questions about intestinal participation in obesity development. The evidence from experimental studies suggests that sustained exposure of rats to a high-fat diet results in permanently increased intestinal alkaline phosphatase (AP) activity (Mozeš et al. 2007, Mozeš et al. 2008a,b). AP is a crucial enzyme highly expressed in the brush border-bound duodenal enterocytes, decreasing longitudinally to the large intestine (Akiba et al. 2007). Alkaline phosphatase participates in a broad range of physiological processes in the intestine, including regulation of lipid absorption (Lallès 2010). In rats, its activity displays circadian fluctuations closely related to food intake (Martinková et al. 2000), and decreased after food deprivation (Raček et al. 2001, Mozeš et al. 2015).

In the last decade the gut microbiota has also become considered as an environmental factor that contributes to the development of obesity and associated metabolic disease. It has been found that colonization of adult germ-free mice with microbiota from the distal intestine of conventionally raised mice resulted in increase in body fat content despite reduced food intake. 
The same study also revealed that the intestinal microbiota promotes absorption of monosaccharides from the gut lumen and de novo hepatic lipogenesis (Bäckhed et al. 2004). Deeper analysis of the distal intestinal microbiota in genetically obese ob/ob mice, lean and wild-type siblings demonstrated differences in quantity and proportion of two major bacterial phyla, namely the Firmicutes and the Bacteroidetes. Compared with lean mice, however, obese animals have a reduced abundance of Bacteroidetes and a proportional increase in Firmicutes despite a similar diet (Ley et al. 2005). Switching from standard chow to a high-fat diet resulted in decreased number of Bacteroidetes and an increase in Firmicutes (Mozeš et al. 2008a, Hildebrandt et al. 2009, Šefč́́ková et al. 2010, Jiang et al. 2016). The variability of methods analyzing which microbial groups are increased or reduced in the gut after high-fat feeding conditions has led to new animal and human studies with inconsistent findings. For example, based on sequence analysis Lecomte et al. (2015) reported a relative decrease in the abundance of Firmicutes (especially reduced numbers of Lactobacillus species) and an increase in the abundance of Bacteroidetes in rats fed on a high-fat diet. According to Fåk et al. (2015), low- and high-fat diet rats did not significantly differ in their levels of the three bacterial genera (Lactobacillus, Bifidobacterium and Bacteroides) in cecal samples. Contradictory results were also observed in a human study, where a significantly increased proportion of Bacteroides in obese and overweight subjects compared with lean controls were reported (Schwiertz et al. 2010), whereas the evidence from another study suggests no difference between obese and non-obese individuals in the proportion of Bacteroidetes measured in fecal samples (Duncan et al. 2008).

At the present time, however, information about the impact on gut microbial composition and small intestinal functionality of varied pre- and post-weaning dietary manipulation using an obesogenic diet is lacking. Therefore, the purpose of this study was to determine the consequences of elevated fat intake during the mentioned periods for body growth parameters, differences in the numbers of two microbial groups, i.e. Bacteroides/ Prevotella (members of the Bacteroidetes) and Lactobacillus/Enterococcus (members of the Firmicutes) in the small and the large intestine, as well as differences in the jejunal brush border-bound alkaline phosphatase activity in rats exposed to high fat/energy diet.

\section{Material and Methods}

\section{Animals and experimental protocol}

Sprague-Dawley virgin rat dams (Charles River Laboratories, Prague) were mated at 10 weeks of age and individually housed in Plexiglass cages in a temperaturecontrolled environment of $22 \pm 2{ }^{\circ} \mathrm{C}$, relative humidity $(55 \pm 10 \%)$ and $12 \mathrm{~h} \mathrm{light/dark}$ cycle (light on 06:0018:00 h). Within $24 \mathrm{~h}$ of parturition, litter size was adjusted to 10 pups per nest. To induce postnatal overnutrition or normal nutrition in their offspring, rat mothers were divided after parturition into two dietary groups: a) a control (C) group with free access to a standard laboratory diet (Laboratory diet M1, Ricmanice, Czech Republic; containing $3.2 \mathrm{kcal} / \mathrm{g}$, with $26.3 \%$ energy as protein, $9.5 \%$ as fat and $64.2 \%$ as carbohydrate) and b) a high-fat diet (HF) group which were given access to the same standard diet ad libitum but were additionally given access to a high-fat/energy diet (high-energy nutritional liquid product Ensure Plus containing $1.5 \mathrm{kcal} / \mathrm{ml}$, with $16.7 \%$ energy as protein, $30 \%$ energy as fat and $53.3 \%$ energy as carbohydrate).

The weaned male rats (day 21) from Control and HF mothers were randomly divided into two dietary groups. Half of the rats (10) nursed by control dams continued on a standard pellet diet (C), while the other half (10) were exposed to the standard diet as well as liquid high-fat diet Ensure Plus until day $40(\mathrm{C} \rightarrow \mathrm{HF})$. Half of the rats (10) nursed by HF dams continued on $\mathrm{HF}$ diet $(\mathrm{HF})$, whereas the other half (10) were given access to standard pellet diet only $(\mathrm{HF} \rightarrow \mathrm{C})$. The animals from all four groups were individually housed in Plexiglass cages under the same conditions (water, temperature, relative humidity, light/dark regime) as before weaning. The food intake in all groups was monitored daily. The animals were killed on days 20 and 40 between 08:00 and 09:00 $\mathrm{h}$ by decapitation followed by removal of the bilateral epididymal plus perirenal adipose depots and jejunal segments for enzyme assay and for enumeration of bacteria.

\section{Milk composition}

The dams were milked on day 11 of lactation. Milk fat concentration was determined using the crematocrit method of Lucas et al. (1978) and expressed in $\mathrm{g} / 100 \mathrm{ml}$ milk using the formula given by Nagasawa et al. (1989). 


\section{FISH analysis}

Each removed jejunum was sectioned into small pieces, cut longitudinally, washed thoroughly with sterile phosphate-buffered saline (PBS; pH 7.4), and the intestinal mucosa were removed for homogenization. Homogenized mucosa were fixed in $4 \%$ paraformaldehyde (Fluka, Switzerland) overnight at $4{ }^{\circ} \mathrm{C}$ and then stored in equal volumes of phosphate-buffered saline and $96 \%$ ethanol at $-20{ }^{\circ} \mathrm{C}$. The numbers of intestinal microbial communities were assessed using the Fluorescent In Situ Hybridisation method with probes (VBC-Genomics, Austria) Lab158 for Lactobacillus/ Enterococcus sp. group Cy3 - 5' GGTATTAGCA(C/T) CTGTTTCCA 3' (Harmsen et al. 1999), or Bac303 for Bacteroides/Prevotella group FITC - 5' CCAATGTGG GGGACCTT 3' (Manz et al. 1996). An aliquot volume of fixed cells was added to $100 \mu \mathrm{l}$ permeabilization solution Tris/HCl buffer (10 mM Tris, $1 \mathrm{mM} \mathrm{EDTA)}$ at $\mathrm{pH} 6.5$ with $100 \mathrm{mg} / \mathrm{ml}$ lysozyme and treated for $1 \mathrm{~h}$ at $37{ }^{\circ} \mathrm{C}$. Permeabilized samples were mixed with hybridization solution $(900 \mathrm{mM} \mathrm{NaCl}, 20 \mathrm{mM}$ Tris- $\mathrm{HCl}$, pH 8.0, $0.01 \%$ sodium dodecyl sulfate [SDS]), contained a probe $(0.5 \mathrm{pmol} / \mu \mathrm{l})$ and placed in a hybridization apparatus at appropriate temperatures overnight (Bac 303 at $46^{\circ} \mathrm{C}$ and $\mathrm{Lab} 158$ at $50{ }^{\circ} \mathrm{C}$ ). The hybridized samples were vacuum filtered onto $0.2 \mu \mathrm{m}$ polycarbonate membrane filters. A microscope (Olympus, BX 51) fitted with appropriate filters for $\mathrm{Cy} 3$ dye and FITC dye was used for enumeration of bacteria. A minimum of 20 fields were counted for each filter. The number of bacteria was calculated using this formula: number of bacteria/gram of samples $=\mathrm{X} \times \mathrm{M} \times \mathrm{Df} / \mathrm{S}$, where $\mathrm{X}=$ number of positive bacteria per field of view; $M=$ total number of fields per effective filter surface different for each microscope and magnification used; Df = dilution factor; $\mathrm{S}=$ weight amount of samples in grams. Values of microbiota in jejunal and colonic samples are given as $\log$ [no. of bacteria ( $0.1 \mathrm{~g}$ mucosa and content)-1], respectively.

\section{Enzyme assays}

For enzyme assay, small $(0.5 \mathrm{~cm})$ segments of the middle part of the jejunum were immediately removed; the lumen was rinsed in distilled water and samples were frozen in liquid nitrogen. Segments of frozen tissue were cut $(8 \mu \mathrm{m})$ in a cryostat at $-25^{\circ} \mathrm{C}$, and the tissue slices were transferred to glass slides and air-dried. Analysis of alkaline phosphatase activity was performed using a modified simultaneous azocoupling method (Lojda et al. 1979). The incubation medium contained $2.0 \mathrm{mM}$ naphthol
AS-BI phosphate (Sigma, Deisenhofen, Germany), $0.8 \mathrm{mM}$ Hexazotized New fuchsin (Serva, Heidelberg, Germany), and $0.05 \mathrm{M}$ veronal acetate buffer. The sections were incubated at $37^{\circ} \mathrm{C}$ for $10 \mathrm{~min}$ at $\mathrm{pH} 8.9$ (Mozeš et al. 1998). Histochemically-stained slides were visualized by means of image analysis and the quantification of the enzyme activity (pixel intensities) was carried out in a whole section of at least four jejunal slides, and then the mean values recorded were referred to one animal (Šefčíková et al. 2008).

\section{Ethics statement}

All animal experiments were reviewed and approved by the Ethical Committee for animal experimentation of the Institute of Animal Physiology, approved by the State Veterinary and Food Administration of the Slovak Republic, and were performed in accordance with Slovak legislation (Law No. 377/2012) on the protection of animals used for experimental and other scientific purposes.

\section{Statistical analysis}

Statistical analyses were carried out using the Statistica AXAZ software package (StatSoftCR, Czech Republic). Data were expressed as mean \pm SEM and statistical significance was accepted at the $\mathrm{P}<0.05$ level. Statistical evaluation of the somatic and small intestinal responses to standard diet versus $\mathrm{HF}$ diet receiving groups was carried out with two-way ANOVA, and Tukey's post hoc test was used to test the effects of age and diet, and their interaction. For comparison of the post-weaning energy intake and weight gain differences between standard and HF diet groups, one-way analysis of variance (ANOVA) followed by Tukey's test was used.

\section{Results}

\section{Milk composition}

Exposure of rat dams to $\mathrm{HF}$ diet resulted in significantly-increased milk fat concentration on postpartum day 11. Comparing control dams with HF dams, the mean values of milk fat concentration expressed in $\mathrm{g} / 100 \mathrm{ml}$ milk were $13.0 \pm 0.58$ vs. $18.3 \pm$ $0.92 \mathrm{~g} / 100 \mathrm{ml}$, respectively $(\mathrm{p}<0.001)$.

During lactation period in HF diet-receiving dams as compared with those fed the control diet significantly increased mean energy intake $213.5 \pm$ $8.7 \mathrm{kcal} /$ day vs. $168.5 \pm 4.1 \mathrm{kcal} /$ day, $\quad(\mathrm{p}<0.01) \quad$ was recorded, respectively. 


\section{Effect of pre-weaning dietary manipulation}

There were no significant differences in the average body weight between pups of control and HF dams on postpartum day 1 ( $7.6 \pm 0.13$ vs. $7.6 \pm 0.22$, respectively). Whereas during the suckling as well as preweaning periods HF pups showed accelerated growth resulting in significantly higher $(\mathrm{p}<0.001)$ body weight and weight gain compared with the Controls (Table 1), in the subsequent post-weaning period however these body weight differences disappeared (Table 2). In HF animals epididymal and perirenal fat pads (expressed in $g$ and in $\%$ body weight) significantly exceeded the values recorded in control rats on day 20 (Figs $1 \mathrm{~A}$ and 1B). Moreover, in these rats significantly-elevated (11\%) jejunal brush-border-bound AP activity was recorded as compared with the controls (Figs 2A and 2B). HF feeding led to an early appearance of diversity in development of gut microbial composition. Due to these changes higher numbers of Lactobacillus/Enterococcus (LAB) and lowered number of Bacteroides/Prevotella (BAC) were found in the jejunum and colon in HF rats (Table 1). The previously acquired differences in body fat accretion, intestinal AP activity as well as microbial composition persisted between Controls versus HF rats until the end of the experiment on day 40 (Tables 2 and 3). Moreover, in the HF rats in comparison with the standard diet-receiving rats $(\mathrm{C})$, significantly higher food intake (expressed in $\mathrm{kcal} /$ day) was recorded during the post-weaning period (Table 2).

Table 1. Somatic and intestinal parameters in 20-day-old male pups nursed by Control or HF diet dams.

\begin{tabular}{lll}
\hline & Control & HF \\
\hline Final body weight $(g)$ & $45.90 \pm 1.22$ & $57.55 \pm 1.62 * * *$ \\
Weight gain (g) (day 1-20) & $38.33 \pm 1.14$ & $49.96 \pm 1.45 * * *$ \\
Alkaline phosphatase (AP) & $15.33 \pm 0.20$ & $17.13 \pm 0.34 * * *$ \\
Jejunum & & \\
Lactobacillus/Enterococcus & $5.48 \pm 0.06$ & $6.64 \pm 0.04 * * *$ \\
Bacteroides/Prevotella & $5.97 \pm 0.10$ & $5.69 \pm 0.10$ \\
Colon & & $7.73 \pm 0.10 * * *$ \\
Lactobacillus/Enterococcus & $6.85 \pm 0.17$ & $6.72 \pm 0.12 *$ \\
Bacteroides/Prevotella & $7.09 \pm 0.10$ & \\
\hline
\end{tabular}

Values are means \pm SEM (8 animals/group). Brush-border-bound jejunal AP activity is given as density values (pixel intensities) at wavelength $520 \mathrm{~nm}$. Values of microbiota in jejunal and colonic samples are given as log (numbers of bacteria/0.1 g jejunal mucosa or $0.1 \mathrm{~g}$ colonic content). Significantly different from control group $* \mathrm{P}<0.05, * * * \mathrm{P}<0.001$ by Tukey's comparison test after one-way ANOVA.

Table 2. Effect of pre- and post-weaning dietary manipulation on somatic and feeding parameters in 40-day-old male rats.

\begin{tabular}{lcccc}
\hline & $\mathbf{C C}$ & $\mathbf{C} \rightarrow \mathbf{H F}$ & $\mathbf{H F} \rightarrow \mathbf{C}$ & $\mathbf{H F}$ \\
\hline Final body weight $(g)$ & $179.3 \pm 4.1$ & $183.6 \pm 4.7$ & $181.7 \pm 5.3$ & $192.1 \pm 6.9$ \\
Weight gain (g) (day 1-40) & $172.8 \pm 4.1$ & $177.0 \pm 4.5$ & $175.1 \pm 5.3$ & $185.4 \pm 6.8$ \\
Mean caloric intake (kcal/day) & $46.7 \pm 1.1$ & $58.5 \pm 1.7^{\mathrm{c}}$ & $45.7 \pm 1.4$ & $59.9 \pm 2.4 * * *+\dagger \dagger$ \\
Caloric intake (kcal) on day 40 & $58.91 \pm 1.78$ & $69.30 \pm 2.75^{\mathrm{a}}$ & $58.27 \pm 2.02$ & $72.75 \pm 3.09 * *+\dagger$ \\
Body fat (\% b. w.) & $0.62 \pm 0.03$ & $0.85 \pm 0.07^{\mathrm{a}}$ & $0.64 \pm 0.06$ & $0.87 \pm 0.06^{*} * \dagger$ \\
\hline
\end{tabular}

Values are means \pm SEM (10 animals/group). Body fat represents epididymal plus perirenal fat pads. Differences between CC vs. HF groups $* * \mathrm{P}<0.01, * * * \mathrm{P}<0.001$; CC vs. $\mathrm{C} \rightarrow \mathrm{HF}$ groups ${ }^{\mathrm{a}} \mathrm{P}<0.05,{ }^{\mathrm{C}} \mathrm{P}<0.001$ and HF vs. HF $\rightarrow \mathrm{C}$ groups ${ }^{\dagger} \mathrm{P}<0.05,{ }^{+\dagger} \mathrm{P}<0.01$, ${ }^{++\dagger} \mathrm{P}<0.001$ by Tukey's multiple comparison test after two-way ANOVA. 

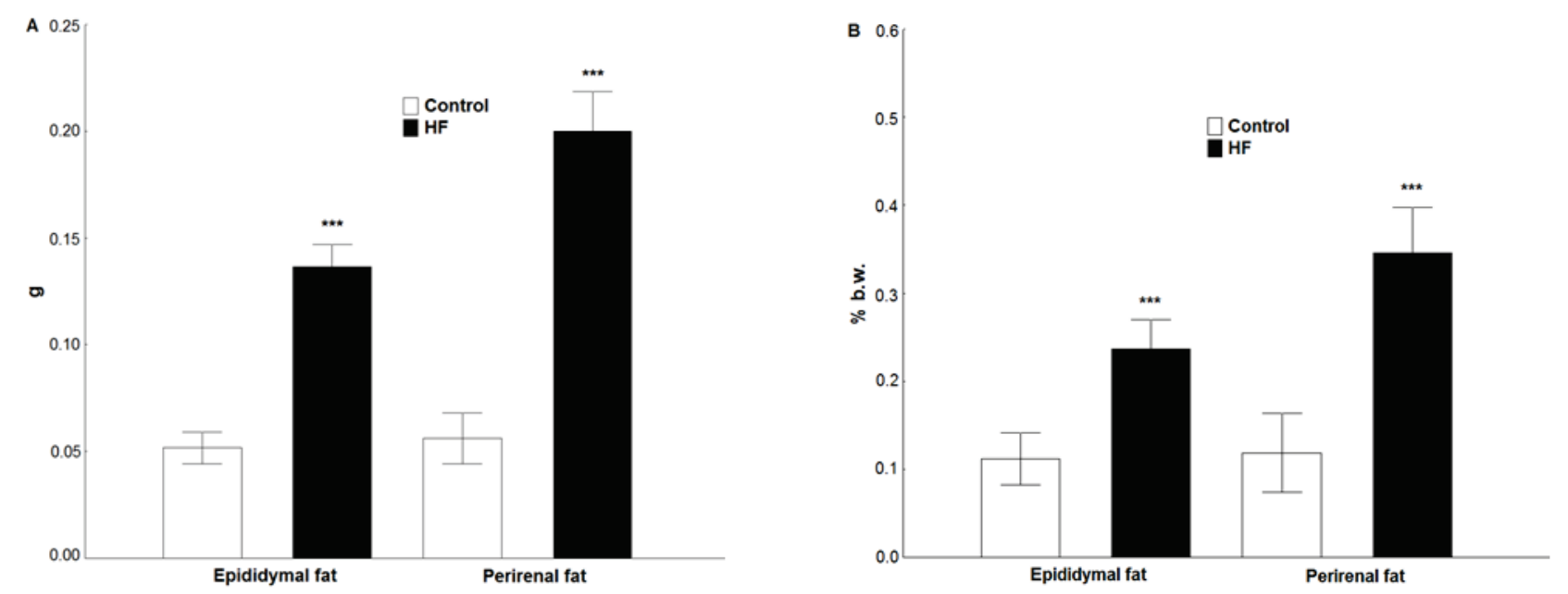

Fig. 1. A. Epididymal and perirenal fat pads (g). B. Epididymal and perirenal fat pads (\% b.w.) in 20-day-old pups nursed by control or $\mathrm{HF}$ dams. Values are means \pm SEM ( $\mathrm{n}=8$ animals/groups). Significantly different from control group $* * * \mathrm{P}<0.001$ by Tukey's comparison test after one-way ANOVA.
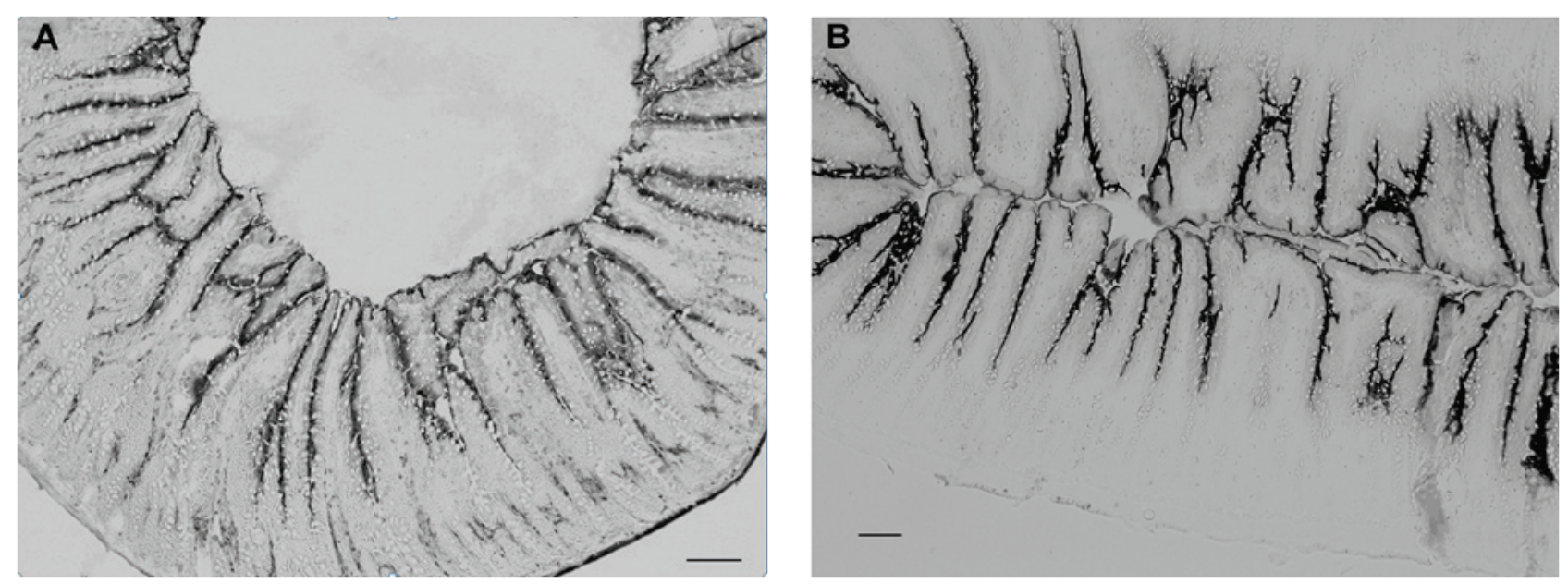

Fig. 2. Histochemical demonstration of jejunal alkaline phosphatase activity in cryosections of 40-day-old CC (control) and HF rats. The enzyme activity is expressed in the brush-border of absorption cells of the intestinal villi in CC (A) and HF (B) rats, (bars $=100 \mu \mathrm{m})$.

Table 3. Effect of pre- and post-weaning dietary manipulations on intestinal parameters in 40-day-old male rats.

\begin{tabular}{lcccc}
\hline & $\mathbf{C C}$ & $\mathbf{C} \rightarrow \mathbf{H F}$ & $\mathbf{H F} \rightarrow \mathbf{C}$ & $\mathbf{H F}$ \\
\hline $\begin{array}{l}\text { Alkaline phosphatase (AP) } \\
\text { Jejunum }\end{array}$ & $12.32 \pm 0.48$ & $14.00 \pm 0.46^{\mathrm{a}}$ & $12.22 \pm 0.50$ & $14.64 \pm 0.29 * * \dagger \dagger$ \\
$\begin{array}{l}\text { Lactobacillus/Enterococcus } \\
\text { Bacteroides/Prevotella }\end{array}$ & $8.16 \pm 0.05$ & $8.64 \pm 0.05^{\mathrm{c}}$ & $8.68 \pm 0.05$ & $8.79 \pm 0.03 * * *$ \\
$\begin{array}{l}\text { Colon } \\
\text { Lactobacillus/Enterococcus }\end{array}$ & $8.72 \pm 0.06$ & $8.10 \pm 0.07^{\mathrm{c}}$ & $7.78 \pm 0.08$ & $7.97 \pm 0.10 * * *$ \\
Bacteroides/Prevotella & $9.13 \pm 0.06$ & $9.53 \pm 0.04^{\mathrm{c}}$ & $9.66 \pm 0.05$ & $9.83 \pm 0.03 * * *$ \\
\hline
\end{tabular}

Values are means \pm SEM (10 animals/group). Brush-border-bound jejunal AP activity is given as density values (pixel intensities) at wavelength $520 \mathrm{~nm}$. Values of microbiota in jejunal and colonic samples are given as log (numbers of bacteria/0.1 g jejunal mucosa) or $0.1 \mathrm{~g}$ colonic content). Differences between CC vs. HF groups ** $\mathrm{P}<0.01, * * * \mathrm{P}<0.001 ; \mathrm{CC}$ vs. $\mathrm{C} \rightarrow \mathrm{HF}$ groups ${ }^{\mathrm{a}} \mathrm{P}<0.05,{ }^{\mathrm{C}} \mathrm{P}<0.001$ and $\mathrm{HF}$ vs. $\mathrm{HF} \rightarrow \mathrm{C}$ groups ${ }^{+\dagger} \mathrm{P}<0.01$ by Tukey's multiple comparison test after two-way ANOVA. 


\section{Effect of post-weaning dietary manipulation}

High-fat diet feeding after weaning resulted in higher fat pad weights expressed as the percentage of body weight in $\mathrm{C} \rightarrow \mathrm{HF}$ rats (Table 2). Increased energy intake by $25 \%$ in these rats led to significantly-elevated alkaline phosphatase activity in the jejunum. Dietary manipulation also significantly influenced the intestinal microbial parameters. In $\mathrm{C} \rightarrow \mathrm{HF}$ rats higher numbers of Lactobacillus/Enterococcus group (LAB) and reduced numbers of Bacteroides/Prevotella group (BAC) in the jejunum and colon were discovered on day 40 , whereas control rats on the standard diet were characterized by lower LAB and elevated BAC numbers (Table 3).

On the other hand, transfer of rats from high-fat diet to control diet $(\mathrm{HF} \rightarrow \mathrm{C})$ from day 21-40 led to a significant reduction in body fat pads expressed in $\mathrm{g} /$ b.w. $(\mathrm{p}<0.05)$ as well as to significantly decreased food intake (kcal/day) at about $31 \%$ as compared to HF rats (Table 2). Moreover, in these $\mathrm{HF} \rightarrow \mathrm{C}$ rats decreased alkaline phosphatase activity in jejunal brush border bound enterocytes was recorded as compared to the $\mathrm{HF}$ group. In $\mathrm{HF} \rightarrow \mathrm{C}$ rats no significant differences in gut microbiota composition were observed after nutritional challenge in the post-weaning period (Table 3).

\section{Discussion}

Obesity and overweight are major public health problems resulted from long-lasting disbalance between energy intake and expenditure. The purpose of this study was therefore to determine whether the transfer of a) normal-fed rats before weaning to obesogenic high-fat/ energy diet after weaning and b) HF-fed rats during the pre-weaning period to control diet after weaning could affect their previously acquired gut microbial composition, enzyme activity and related parameters of growth.

In the current study we observed that HF feeding from birth until weaning contributed to the development of obesity, i.e. in pups nursed by HF mothers in comparison with normal-fed controls we found significantly increased fat deposition on day 20 and 40 accompanied with elevated alkaline phosphatase (AP) activity in jejunal enterocytes. Regarding the role of intestinal enzymes, AP is considered as a brush borderbound representative enzyme that participates in lipid absorption (Lallès 2010), and it is stimulated by fat consumption (Kaur et al. 2007, Lallès et al. 2012, Šefčíková and Raček 2016). Besides this function, AP also plays a role in the maintenance of normal gut microbial homeostasis (Malo et al. 2010, Malo et al. 2014). With respect to the gut microflora, it was previously reported that mice deficient in the brush-border intestinal alkaline phosphatase enzyme displayed dramatically fewer and also different types of aerobic and anaerobic microbes in their stools compared with their wild-type littermates (Malo et al. 2010).

Although the gut microbiota remains relatively stable throughout life, changes in the host diet may markedly influence its composition. This was supported by significantly reduced relative abundance of Bacteroidetes and higher Firmicutes to Bacteroidetes ratio in obese animals and humans after increased fat intake (Zhang et al. 2012, Kasai et al. 2015). Moreover, a previous study performed on a humanized mouse model (germ-free mice received human gut microbiota) indicated that switching from a low-fat, plant polysaccharide-rich diet to a high-fat, high-sugar "Western" diet changed the microbiota within a single day (Turnbaugh et al. 2009). Similarly, the results from the current work reveal reduced numbers of Bacteroides/Prevotella (BAC) and higher numbers of Lactobacillus/Enterococcus (LAB) in the small and large intestine of $\mathrm{HF}$ animals in comparison with controls.

Although based on the recent studies it has been demonstrated that the gut microbiota plays an important role in the control of energy homeostasis and obesity development, these data are conflicting. On the one hand Bäckhed et al. (2007) reported that, in contrast to mice with gut microbiota, germ-free animals were protected against obesity that develops after consuming a Westernstyle, high-fat, sugar-rich diet. On the other hand, it was observed that the absence of gut microbiota did not provide general protection from diet-induced obesity; i.e. germ-free mice on the high-fat diet gained more body weight and body fat than conventional mice, and had lower energy expenditure (Fleissner et al. 2010).

Our study also indicates that exposure of control rats to a diet with higher fat content $(\mathrm{C} \rightarrow \mathrm{HF})$ after weaning from day 21 to day 40 led to significantly elevated fat pads accretion and substantially higher jejunal AP activity. Consumption of HF diet modified not only the somatic and enzymatic/functional status of our rats, but also their quantitative and proportional gut microbiota, i.e. in $\mathrm{C} \rightarrow \mathrm{HF}$ animals higher $\mathrm{LAB}$ and lower numbers of BAC were found compared to the control rats. This is in accordance with a previous study in which post-weaning consumption of a high-fat diet resulted in 
jejunal microbial and functional alterations in obese rats (Šefčíková et al. 2010). On the other hand, transfer from high-fat to control diet after weaning in $\mathrm{HF} \rightarrow \mathrm{C}$ rats resulted in evidently decreased body fat deposition (expressed in $\mathrm{g} / \mathrm{b}$.w.) as well as significantly lower brush border-bound AP activity in jejunal enterocytes compared to HF rats. Our data also show that these fat-reducing and enzymatic changes were not accompanied with apparent differences in microbial quantity and composition in $\mathrm{HF} \rightarrow \mathrm{C}$ rats compared to HF rats. This is in contrast to another study, where after switching to normal chow feeding, the gut microbiota in the DIO group soon moved back to control values, and differences in the diversity, overall structure and composition of the gut microbiota were not recorded between the two groups (Zhang et al. 2012). These contradictory data may result from different age of tested animals and various experimental periods and methods used in the experiments.

In the future it would be interesting to focus on the complex interaction between diet, intestinal microbial/enzymatic adaptability and their impact on gut health.

In summary, our present study provides information about altered composition of the gut microbiota and enzyme activity in response to consumption of a high-fat diet by male Sprague-Dawley rats during pre- and post-weaning periods. Changing from an obesogenic diet to normal feeding conditions in the post-weaning period did not improve acquired gut microbial alterations. To produce more conclusive data, another study is needed to establish the importance of gut microbiota for the control of body weight and energy homeostasis in overfed rats. Knowledge about potential variations in microbial composition in the context of obesity may be helpful for novel pharmacological and dietary strategies in prevention or attenuation of obesity and its related metabolic disorders.

\section{Conflict of Interest}

There is no conflict of interest.

\section{Acknowledgements}

The authors thank Andrew Billingham for his revision of the English text and Dr. Štefan Mozeš for his useful comments. This study was supported by VEGA grants 2/0011/14 and 2/0001/14 of the Slovak Academy of Sciences.

\section{References}

AKIBA Y, MIZUMORI M, GUTH PH, ENGEL E, KAUNITZ JD: Duodenal brush border intestinal alkaline phosphatase activity affects bicarbonate secretion in rats. Am J Physiol Gastrointest Liver Physiol 293: G1223-G1233, 2007.

BÄCKHED F, DING H, WANG T, HOOPER LV, KOH GY, NAGY A, SEMENKOVICH CF, GORDON JI: The gut microbiota as an environmental factor that regulates fat storage. Proc Natl Acad Sci USA 101: 15718-15723, 2004.

BÄCKHED F, MANCHESTER JK, SEMENKOVICH CF, GORDON JI: Mechanisms underlying the resistance to diet-induced obesity in germ-free mice. Proc Natl Acad Sci USA 104: 979-984, 2007.

DUNCAN SH, LOBLEY GE, HOLTROP G, INCE J, JOHNSTONE AM, LOUIS P, FLINT HJ: Human colonic microbiota associated with diet, obesity and weight loss. Int J Obes (Lond) 32: 1720-1724, 2008.

FÅK F, JAKOBSDOTTIR G, KULCINSKAJA E, MARUNGRUANG N, MATZIOURIDOU C, NILSSON U, STÅLBRAND H, NYMAN M: The physico-chemical properties of dietary fibre determine metabolic responses, short-chain fatty acid profiles and gut microbiota composition in rats fed low- and high-fat diets. PLoS One 10: e127252, 2015.

FLEISSNER CK, HUEBEL N, ABD EL-BARY MM, LOH G, KLAUS S, BLAUT M: Absence of intestinal microbiota does not protect mice from diet-induced obesity. Br J Nutr 104: 919-929, 2010.

HARMSEN HJM, ELFFERICH P, SCHUT F, WELLING GW: A 16S rRNA-targeted probe for detection of lactobacilli and enterococci in faecal samples by fluorescent in situ hybridization. Microb Ecol Health Dis 11: 3-12, 1999.

HILDEBRANDT MA, HOFFMANN C, SHERRILL-MIX SA, KEILBAUGH SA, HAMADY M, CHEN YY, KNIGHT R, AHIMA RS, BUSHMAN F, WU GD: High-fat diet determines the composition of the murine gut microbiome independently of obesity. Gastroenterology 137: 1716-1724, 2009. 
JIANG T, GAO X, WU C, TIAN F, LEI Q, BI J, XIE B, WANG HY, CHEN S, WANG X: Apple-derived pectin modulates gut microbiota, improves gut barrier function, and attenuates metabolic endotoxemia in rats with diet-induced obesity. Nutrients 8: 126, 2016.

KASAI C, SUGIMOTO K, MORITANI I, TANAKA J, OYA Y, INOUE H, TAMEDA M, SHIRAKI K, ITO M, TAKEI Y, TAKASE K: Comparison of the gut microbiota composition between obese and non-obese individuals in a Japanese population, as analyzed by terminal restriction fragment length polymorphism and next-generation sequencing. BMC Gastroenterol 15: 100, 2015.

KAUR J, MADAN S, HAMID A, SINGLA A, MAHMOOD A: Intestinal alkaline phosphatase secretion in oil-fed rats. Dig Dis Sci 52: 665-670, 2007.

LALLÈS JP: Intestinal alkaline phosphatase: multiple biological roles in maintenance of intestinal homeostasis and modulation by diet. Nutr Rev 68: 323-332, 2010.

LALLÈS JP, OROZCO-SOLÍS R, BOLAÑOS-JIMÉNEZ F, DE COPPET P, LE DRÉAN G, SEGAIN JP: Perinatal undernutrition alters intestinal alkaline phosphatase and its main transcription factors KLF4 and Cdx1 in adult offspring fed a high-fat diet. J Nutr Biochem 23: 1490-1497, 2012.

LECOMTE V, KAAKOUSH NO, MALONEY CA, RAIPURIA M, HUINAO KD, MITCHELL HM, MORRIS MJ: Changes in gut microbiota in rats fed a high fat diet correlate with obesity-associated metabolic parameters. PLoS One 10: e0126931, 2015.

LEY RE, BÄCKHED F, TURNBAUGH P, LOZUPONE CA, KNIGHT RD, GORDON JI: Obesity alters gut microbial ecology. Proc Natl Acad Sci USA 102: 11070-11075, 2005.

LOJDA Z, GOSSRAU R, SCHIBLER TH: Enzyme Histochemistry. Springer, Berlin, 1979, pp 59-70.

LUCAS A, GIBBS JA, LYSTER RL, BAUM JD: Creamatocrit: simple clinical technique for estimating fat concentration and energy value of human milk. Br Med J 1: 1018-1020, 1978.

MALO MS, ALAM SN, MOSTAFA G, ZELLER SJ, JOHNSON PV, MOHAMMAD N, CHEN KT, MOSS AK, RAMASAMY S, FARUQUI A, HODIN S, MALO PS, EBRAHIMI F, BISWAS B, NARISAWA S, MILLÁN JL, WARREN HS, KAPLAN JB, KITTS CL, HOHMANN EL, HODIN RA: Intestinal alkaline phosphatase preserves the normal homeostasis of gut microbiota. Gut 59: 1476-1484, 2010.

MALO MS, MOAVEN O, MUHAMMAD N, BISWAS B, ALAM SN, ECONOMOPOULOS KP, GUL SS, HAMARNEH SR, MALO NS, TESHAGER A, MOHAMED MM, TAO Q, NARISAWA S, MILLÁN JL, HOHMANN EL, WARREN HS, ROBSON SC, HODIN RA: Intestinal alkaline phosphatase promotes gut bacterial growth by reducing the concentration of luminal nucleotide triphosphates. Am J Physiol Gastrointest Liver Physiol 306: G826-G838, 2014.

MANZ W, AMANN R, LUDWIG W, VANCANNEYT M, SCHLEIFER KH: Application of a suite of 16S rRNAspecific oligonucleotide probes designed to investigate bacteria of the phylum cytophaga-flavobacterbacteroides in the natural environment. Microbiology 142: 1097-1106, 1996.

MARTINKOVÁ A, LENHARDT L, MOZEŠ Š: Effect of neonatal MSG treatment on day-night alkaline phosphatase activity in the rat duodenum. Physiol Res 49: 339-345, 2000.

MOZEŠ Š, LENHARDT L', MARTINKOVÁ A: A quantitative histochemical study of alkaline phosphatase activity in isolated rat duodenal epithelial cells. Histochem J 30: 583-583, 1998.

MOZEŠ Š, ŠEFČÍKOVÁ Z, LENHARDT L: Functional changes of the small intestine in over- and undernourished suckling rats support the development of obesity risk on a high-energy diet in later life. Physiol Res 56: 183-192, 2007.

MOZEŠ Š, BUJŇÁKOVÁ D, ŠEFČ́́KOVÁ Z, KMEŤ V: Developmental changes of gut microflora and enzyme activity in rat pups exposed to fat-rich diet. Obesity 16: 2610-2615, 2008a.

MOZEŠ Š, BUJŇÁKOVÁ D, ŠEFČÍKOVÁ Z, KMEŤ V: Intestinal microflora and obesity in rats. Folia Microbiol 53: 225-228, 2008b.

MOZEŠ Š, ŠEFČÍKOVÁ Z, RAČEK L: Effect of repeated fasting/refeeding on obesity development and health complications in rats arising from reduced nest. Dig Dis Sci 60: 354-361, 2015.

NAGASAWA H, NAITO T, KATAOKA K: Relationship between milk composition and pup's growth in mice. Proc Soc Exp Biol Med 191: 78-81, 1989. 
RAČEK L', LENHARDT L', MOZEŠ Š: Effect of fasting and refeeding on duodenal alkaline phosphatase activity in monosodium glutamate obese rats. Physiol Res 50: 365-372, 2001.

SCHWIERTZ A, TARAS D, SCHAFER K, BEIJER S, BOS NA, DONUS C, HARDT PD: Microbiota and SCFA in lean and overweight healthy subjects. Obesity 18: 190-195, 2010.

ŠEFČÍKOVÁ Z, RAČEK L': Effect of pectin feeding on obesity development and duodenal alkaline phosphatase activity in Sprague-Dawley rats fed with high-fat/high-energy diet. Physiol Int 103: 183-190, 2016.

ŠEFČÍKOVÁ Z, HÁJEK T, LENHARDT L, RAČEK L', MOZEŠ Š: Different functional responsibility of the small intestine to high fat/high-energy diet determined the expression of obesity-prone and obesity-resistant phenotypes in rats. Physiol Res 57: 467-474, 2008.

ŠEFČÍKOVÁ Z, KMEŤ V, BUJŇÁKOVÁ D, RAČEK L', MOZEŠ Š: Development of gut microflora in obese and lean rats. Folia Microbiol 55: 373-375, 2010.

TURNBAUGH PJ, RIDAURA VK, FAITH JJ, REY FE, KNIGHT R, GORDON JI: The effect of diet on the human gut microbiome: a metagenomic analysis in humanized gnotobiotic mice. Sci Transl Med 1: 6ra14, 2009.

ZHANG C, ZHANG M, PANG X, ZHAO Y, WANG L, ZHAO L: Structural resilience of the gut microbiota in adult mice under high-fat dietary perturbations. ISME J 6: 1848-1857, 2012. 